\title{
Feonomies
}

Central European Review of Economics \& Finance

Vol. 30, No. 2 (2019), pp. 33-44

DOI: $10.24136 /$ ceref.2019.006

Received: 4 March 2019. Accepted: 8 April 2019.

MAGDALENA TURCZYN ${ }^{1}$

\section{CENTRALIZATION OF PROCESSES OF SUPPORTING EDUCATIONAL INSTITUTIONS AND ITS CONSEQUENCES IN THE BUDGET OF THE COMMUNE}

\begin{abstract}
Shared Services Center have been developing well for the last few years in Poland as well as in the world. Advantages of the centralization of the processes 'back-office' in private businesses are not insignificant, therefore this solution have been introduced and recommended to the local government units. The main purpose of this article was to diagnose if the centralization of support processes for commune educational institutions in the voivodeships Podkarpackie in Shared Service Centers, brings effects in the form of lowering costs handling these processes. After analyzing the data, the results confirming the thesis were obtained. In the studied period of years 2014-2017, despite rising expenes for education, the direct costs related to employees servicing support processes were decreasing. It causes the necessity of insightful analysis of the problem from different aspects, but it also allows us to suppose that the implementation of solutions developed in education system would also be effective in other areas of activity of local government units, which would optimalize costs and bring significant savings.
\end{abstract}

Keywords: Shared Services Center, back-office, educational institution.

JEL Classification Codes: H52.

\section{Introduction}

Shared Services Center have been developing well for the last few years in Poland as well as in the world. Advantages of the centralization of the processes 'back-office' in private businesses are not insignificant, therefore this solution have been introduced

\footnotetext{
${ }^{1}$ M.Sc., University of Rzeszów.
} 
and recommended to the local units government. Is the organization of areas of support within the Shared Services Center in self-government educational institutions have an opportunity for improvement of the financial condition of Polish communes? Or maybe is it a chance for financial surpluses? Certainly, it creates an opportunities to optimize costs and thus to achieve specific savings of financial resources.

This article certainly does not cover all aspects and implications of centralization of support processes, the author treats it as an introduction to the discussion of the needs for centralization of auxiliary processes within Shared Service Centers in public administration institutions, and its effects in the optimization of public finances.

The subjective and objective field of this article includes the analysis of the number of Economic and Administrative School Complexes, and Shared Service Centers functioning in the broadly understood sphere of education and its changes, as well as an analysis of communes expenditure on the functioning of the support area for communal educational facilities in 2014-2017.

As the main goal, an attempt was made to assess the impact of centralization of support processes for educational institutions under SSC or Economic and Administrative School Complex on the level of expenditure in this area, in the communes of the Podkarpackie voivodeship in the years 2014-2017.

The following research hypothesis was formulated: Centralization of the support function of communal educational institutions effects reduction in outlays and the reduction in the costs of educational institutions within the communes of the Podkarpackie voivodeship.

In this elaboration, based on statistical data from the Statistical Office, the expenditure of communes and cities with poviat rights in the Podkarpackie voivodeship has been analyzed as well as their share of expenses on SSC/ EASC. The expenditure of communes in department 801, ie. education and upbringing in 2014-2107, was also analyzed.

On the basis of materials from the Ministry of National Education, the number and structure of EASCs or SSCs institutions created in the scale of the whole country as well as the Podkarpackie region in 2014-2017 were presented. There was also pointed out that there's a tendency in the structure of employment and salaries of non-pedagogical employees, i.e., employees of support departments, eg. accounting and administration. An attempt was made to summarize and assess whether the centralization of support processes for municipal educational and upbringing institutions contributes to the reduction of communes expenditure on their functioning. Final conclusions have also been drawn.

\section{Shared Service Center - idea, benefits, possibilities}

Shared Service Center (SSC) is an organisationally separated unit that provides administrative and financial services to several subjects. The mechanism of so-called 
shared service centers is very popular in the private sector. Private enterprises more and more often create for their branches accounting service centers, centers implementing HR processes, IT support, shopping, managing real estate, etc., thus relieving branches from the implementation of these tasks by each of them separately. Since the beginning of the 1990s, international centers have been established in large numbers, which support the support processes for many business units in many countries.

Creating a Shared Services Center has several advantages. One of the most important ones is to eliminate the duplication of repetitive activities, not falling within the basic field of activity of a given organizational unit, by employees of dispersed units, and what is connected with the reduction of service costs, in particular, administrative, financial and organizational, and providing them from one, central place. This translates directly to improving the efficiency and quality of the services provided. Organizational consolidation takes place as well as unification of service standards by setting common criteria and principles of operation, as well as streamlining internal processes in individual organizational units, which directly affects the improvement of the quality of functioning and makes it possible to focus only on the substantive aspect of the basic activity of a given company. There is also a noticeable increase in the transparency of the operation of individual organizational units.

\section{Shared Service Centers in public administration in the world and in Poland}

The potential of using shared service centers to bring savings has been noticed by the authorities of many countries. The leading countries in the organization of Shared Service Centers in the public sector in Europe include: UK, Ireland, Sweden, Norway; and non-European countries: USA, Australia, New Zealand or Singapore. For example, the United Kingdom's governmental strategy of 2005 on changes in the public sector states that "the implementation of modern shared service centers is necessary to improve the efficiency of public administration and to better support the implementation of public tasks in a more focused way on the needs of citizens".

In 2014, 257 local governments operated in the model of shared services center in England, and the savings resulting from their operation are estimated at GBP 357 million.

As a Polish example, it is worth quoting SSC poviat Kętrzyński. The project to create SSC was completed in 2015. And included areas such as accounting, human resources, payroll, purchasing and IT services. The amount of units subordinated to one of the SSC's is 11 which includes: 4 schools, Youth Culture Center and Public Library or Sports and Tourism Recreation Center. Before the reorganization, there were 19,5 job positions with 24 employees. After the reorganization the amount of job positions decreased to 
6,5 with 11 employees. On an annual basis, these are significant savings. After the introduction of shared service, the local government unit managed to obtain a $20 \%$ reduction in the costs of purchasing services for the region. To realize how significant are processes that the SSC can handle (in this particular case - poviat Kętrzyński) it is annually 9,500 accounting documents, handling about 370 job contracts or 91 contracts signed for the supply of services and goods.

Local government units are undoubtedly one of the largest providers of public services in the country. Until now, however, shared service for institutions and establishments providing public services could only be implemented in a relation to a certain statutory services. The law on the education system for over 10 years enables bodies that run schools and other educational institutions to organize shared administrative, financial and organizational services. The existing data on shared economic and administrative service of schools, shows that a local governments are quite readily benefited from this possibility - almost $50 \%$ of all communes set up the economic and administrative service teams for schools and institutions. As you can see in the example above, experiences from projects implemented so far are very encouraging and this allows us to believe that this model of organizing the support areas of self-government institutions has a chance to be widely accepted in Poland. The needs in terms of improving the efficiency of property and service management are enormous, which means that the potential for shared service centers is very significant.

Over time, SSCs may appear in various niche areas - those that we currently do not associate with this organizational form, e.g. in healthcare facilities or other local government entities.

\section{Possibilities and directions of changes on the functioning of support areas for municipal educational institutions}

One can not be convinced that the local governments in Poland will find new possibilities for financing their units in the near future. The growth of Polish economy is largely predictable, which allows us to expect slight changes in local government funds. Financial resources from the European Union will also be limited in a certain time perspective. The amount of financial resources directed to local governments for the implementation of their own tasks and commissioned by the government, rather does not allow local governments to generate enough surpluses from which they could finance their activities or developement. Significant funds also absorb own shares of local governments in projects financed from European Union funds. All this results in a considerable level of indebtedness of communes and poviats. This situation is not improved by the fact that due to the migration of population and demographic changes, local governments income falls. For many local governments, SSCs are probably the only effective way to 
deal with these unfavorable trends. It is worth to take an example of a well-functioning SSC from a business. Those applied solutions bring significant savings each year and are improving its functioning.

Outsourcing of processes and creation of Shared Service Centers, which have been successfully adopted in private enterprises, can now be transferred to the local government areas. The amended provisions allow territorial self-government units to reorganize their activities. The act passed by the Parliament on June 25th of the 2015 amending the act on municipal self-government and some other acts, which has been in force since January 1 st of the 2016 opens the possibility of a wide application of the mechanism of shared services in self-governments. Municipalities, poviats, voivodships can already create units providing joint administrative, financial and accounting services for their own organizational units. As rightly pointed out in the explanatory memorandum to the bill, the creation of a shared service will allow a number of savings, among others as a result of a better use of available resources. It'll also ensure reduction of operating costs and specializations. It should also help to improve the quality of processes through standardization which will also allow for more flexible unit management. The functioning of the Shared Service Centers will also enable to use of economies of scale, e.g. in the process of conducting joint public procurement.

In the experts opinion, thanks to the act adopted by the parliament, it will be possible to solve many problems that arise from the public sector's high concentration on the current service of citizens and relatively low emphasis on improving the way public services operate. Shared Service Centers are to contribute to reducing the costs associated with administrative service, improving the functioning and organization of public tasks performed by local government units. This will enable organizational consolidation of the Polish local government (dispersed today), which, unfortunately, does not yet have the real freedom to shape its own structures. It is overpowered by the necessity of having specific institutions, such as social assistance centers, cultural institutions, etc. There are over 50,000 of them, some of whom employ only a few people (3-5), but each must have a chief accountant and manager. This generates high administrative costs for local government units, often with a low efficiency, which is a great burden with a constant shortage of funds. SSCs are intended to rationalize the operating costs of local government organizational units and to increase work efficiency.

\section{Results of centralization of the support area of municipal educational institutions in Podkarpackie voivodeship in the years 2014-2017}

In Polish local governments, for many years, at every level (especially at the level of municipalities) the area of support, i.e. accounting and financial or administrative service of educational institutions, is in a certain extent centralized. Many of these types of 
facilities have already handed these tasks to the Economic and Administrative School Complexes, which from 2016 onwards with the entry into force of the new law are transformed into Communal Shared Service Centers, serving not only schools and kindergartens, but also nurseries, libraries, youth hostels and other such facilities located in a given area. In many cases, also financial and accounting, HR and administration services are also carried out by a department specially designated for this purpose in the commune and it is also a kind of a central service. There are, however, many educational institutions which until now have been providing services in the aforementioned scope independently, with their own resources. The analysis of the experience of individuals using various forms of organization of support processes, can be the basis for identifying the most effective solutions in this area.

The table 1 presents the scale of the phenomenon, i.e. the number of self-government EASC/SSC established in Poland and changes in their number in 2014-2017.

Table 1. The number of self-governmental SSC/EASC in voivodeships in Poland, in 2014-2017

\begin{tabular}{|c|c|c|c|c|c|c|c|}
\hline \multirow{2}{*}{ Voivodeship } & \multirow{2}{*}{$\begin{array}{c}2014 \\
\text { EASC }\end{array}$} & \multirow{2}{*}{$\begin{array}{c}2015 \\
\text { EASC }\end{array}$} & \multicolumn{2}{|c|}{2016} & \multicolumn{2}{|c|}{2017} & \multirow{2}{*}{\begin{tabular}{|c|}
2017 vs. 2014 \\
Transition \\
\end{tabular}} \\
\hline & & & SSC & EASC & SSC & EASC & \\
\hline Dolnośląskie & 27 & 26 & 2 & 23 & 7 & 12 & -8 \\
\hline Kujawsko-pomorskie & 58 & 57 & 2 & 56 & 19 & 36 & -3 \\
\hline Lubelskie & 67 & 64 & & 63 & 10 & 39 & -18 \\
\hline Lubuskie & 20 & 18 & & 18 & 7 & 11 & -2 \\
\hline Łódzkie & 53 & 51 & 3 & 41 & 13 & 23 & -17 \\
\hline Małopolskie & 125 & 125 & 9 & 111 & 38 & 68 & -19 \\
\hline Mazowieckie & 135 & 130 & 4 & 120 & 29 & 61 & -45 \\
\hline Opolskie & 31 & 29 & & 29 & 3 & 23 & -5 \\
\hline Podkarpackie & 89 & 90 & 4 & 86 & 24 & 51 & -14 \\
\hline Podlaskie & 22 & 21 & 2 & 15 & 4 & 11 & -7 \\
\hline Pomorskie & 37 & 36 & 5 & 30 & 10 & 19 & -8 \\
\hline Śląskie & 94 & 93 & 5 & 86 & 12 & 58 & -24 \\
\hline Świetokrzyskie & 50 & 50 & 2 & 44 & 30 & 13 & -7 \\
\hline Warmińsko-mazurskie & 35 & 31 & 2 & 27 & 6 & 17 & -12 \\
\hline Wielkopolskie & 81 & 81 & 2 & 72 & 29 & 31 & -21 \\
\hline Zachodniopomorskie & 25 & 27 & 1 & 22 & 6 & 12 & -7 \\
\hline Total & 949 & 929 & 43 & 843 & 247 & 485 & -217 \\
\hline
\end{tabular}

Source: own study based on data from the Ministry of National Education.

As presented above, in all voivodeships in 2014-2017, the number of SSCs have decreased by 217 , from 949 in 2014 to 732 in 2017 . According to preliminary analyzes, this is related to the systematic transformation of EASC in the SSC during this period, increasing the coverage of SSC services, and thus the elimination of some EASCs. 


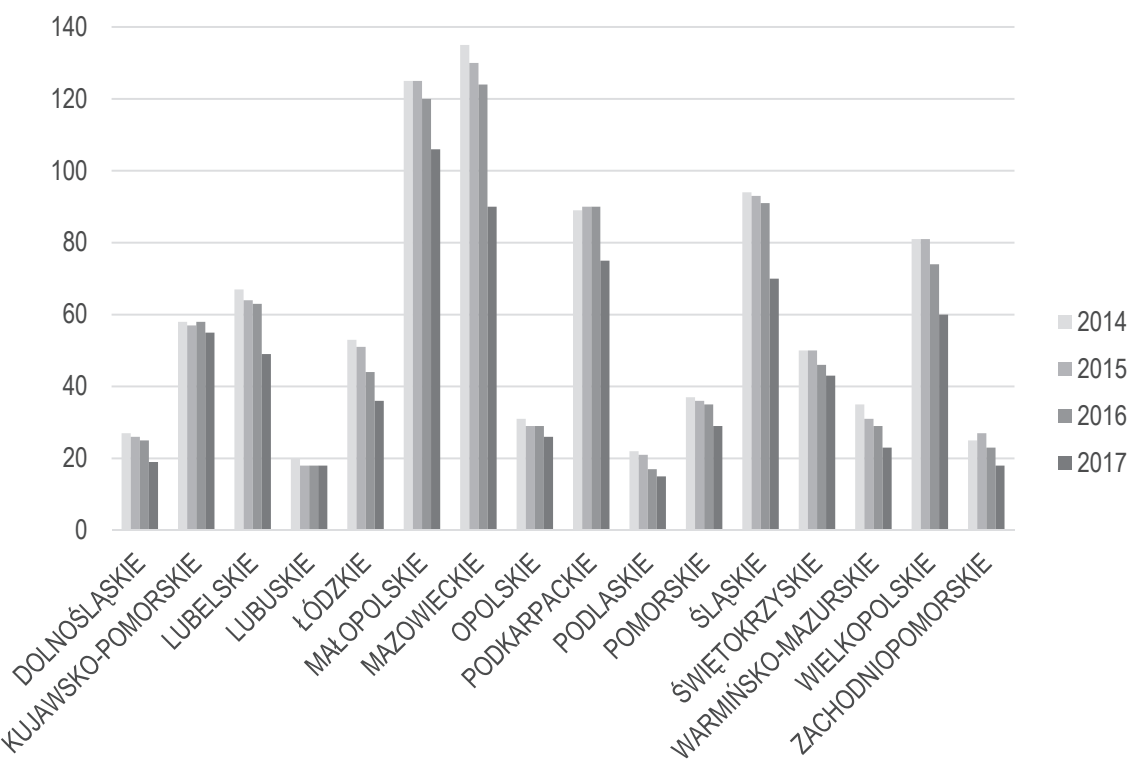

Figure 1. The number of self-governmental SSC/EASC in voivodeships in Poland in 2014-2017

Source: own study based on data from the Ministry of National Education.

According to the first analyzes, there are many municipalities in Poland, where such center has not been created so far and so the service is dispersed, i.e. carried out by employees resources from the level of a given institution.

In Poland, Shared Service Centers that are providing financial, accounting and administrative services for educational facilities are located at all levels of local selfgovernment. The structure of the location of these branches in Poland is shown in the table 2.

Table 2. Location of SSCs/EASCs in Poland in 2014-2017

\begin{tabular}{|l|r|r|r|r|r|}
\hline \multicolumn{1}{|c|}{ Location/amount } & $\mathbf{2 0 1 4}$ & $\mathbf{2 0 1 5}$ & $\mathbf{2 0 1 6}$ & $\mathbf{2 0 1 7}$ & Transition 2017 vs. 2014 \\
\hline Municipality & 882 & 861 & 815 & 669 & -213 \\
\hline City with poviat rights & 19 & 21 & 22 & 19 & 0 \\
\hline Poviat & 48 & 47 & 49 & 44 & -4 \\
\hline Total & 949 & 929 & 886 & 732 & -217 \\
\hline
\end{tabular}

Source: own study based on data from the Ministry of National Education.

As presented in the table, the vast majority of these units (over 90\%) are a communal Shared Service Centers. 


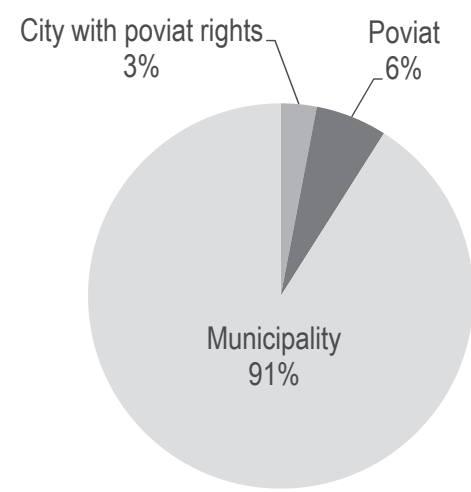

Figure 2. Location of SSCs/EASCs in Poland - structure in 2017

Source: own study based on data from the Ministry of National Education.

In the Podkarpackie voivodeship, financial and administrative and HR services for many educational institutions are also implemented through Shared Service Centers. In the Podkarpackie voivodeship the majority of local self-government SSCs are located at the lowest level of local government (in municipalities). The very same tendency was observed throughout the Poland, which gives the possibility of wide and credible research in this area. The table 3 presents the location of SSC / EASC in the Podkarpackie voivodeship. On 160 municipalities in the Podkarpackie voivodeship about 70 of them are organized in the form of SSC.

Table 3. Location of SSCs/ EASC in the Podkarpackie voivodeship in the years 2014-2017

\begin{tabular}{|c|c|c|c|c|c|c|c|}
\hline Location/amount & 2014 & 2015 & \multicolumn{2}{|c|}{2016} & \multicolumn{2}{|c|}{2017} & 2017 vs. 2014 \\
\hline SSC/EASC & EASC & EASC & SSC & EASC & SSC & EASC & Transition \\
\hline Municipality & 84 & 85 & 2 & 82 & 21 & 49 & -14 \\
\hline City with poviat rights & 1 & 1 & & & 1 & & 0 \\
\hline Poviat & 4 & 4 & 2 & 4 & 2 & 2 & 0 \\
\hline Total & 89 & 90 & 4 & 86 & 24 & 51 & -14 \\
\hline
\end{tabular}

Source: own study based on data from the Ministry of National Education.

As presented in the table in the years 2014-2017, the number of SSCs decreased from 84 to 70, which according to preliminary analyzes is related to the process of transforming EASCs into SSCs, and thus increasing the coverage of services in communes and the elimination of some EASCs.

Preliminary analyzes of statistical data obtained at the Ministry of National Education regarding the number of employees and remuneration of employees in the area of accounting and administration in local government SSC allow to conclude that thanks 
to the transfer of support processes to Shared Service Centers at the local government level, savings can be generated. In most of the voivodeships there was a decrease in the number of employees of this area, and a decrease in the expenditure on wages, which, with the same range of tasks of educational institutions in the municipality, may indicate an increase in efficiency.

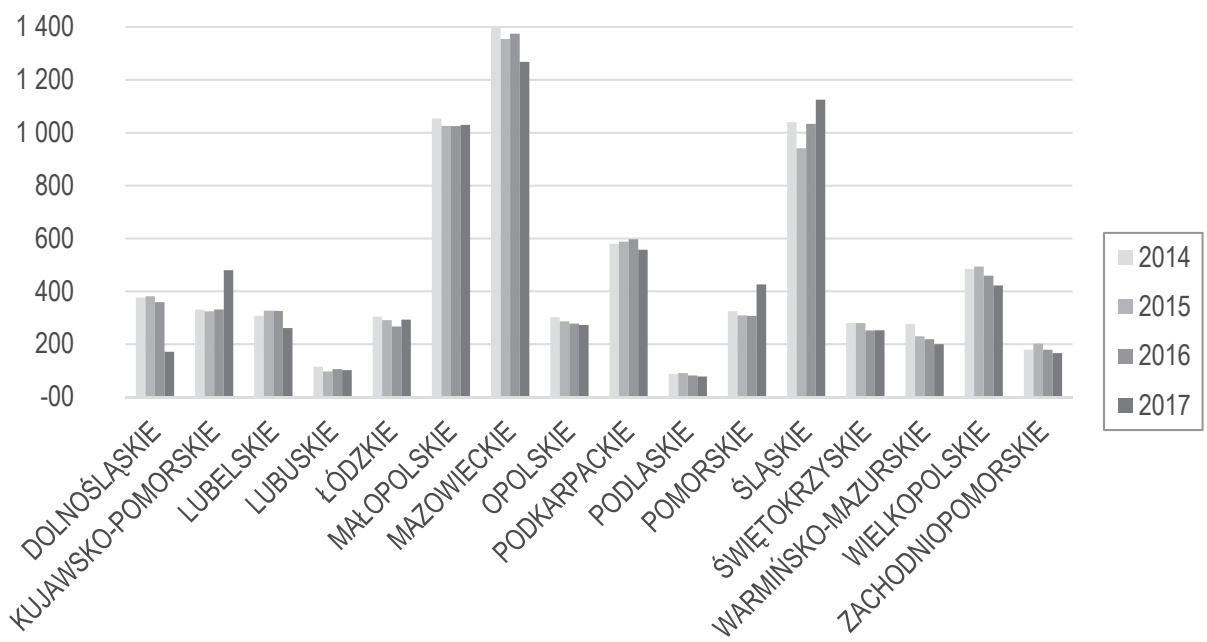

Figure 3. Number of administrative employees employed in SSC/EASC (job positions)

Source: own study based on data from the Ministry of National Education.

As can be seen from the Fig 1, only in 3 voivodeships (Kujawsko-Pomorskie, Pomorskie and Ślaskie) the number of employees in SSCs have increased in the period under consideration.

The average monthly value of SSC / EASC accounting and administrative staff salaries in 2014-2017 is presented in Fig. 4.

As it results from the Fig. 4 , only in 4 voivodeships (Kujawsko-Pomorskie, Małopolskie, Pomorskie and Śląskie) in the period under consideration, the value of employees wages have increased.

Fig. 5 shows the share of expenditure on SSC / EASC in the total expenditure of communes and cities with poviat rights in Poland in the years 2003-2016 (in milion PLN).

As can be seen from the Fig. 5, despite the fact that the total expenditure of communes and cities with poviat rights in Poland in the period under consideration systematically increased from less than 25 million PLN in 2003 to nearly 55 million PLN in 2016, the share of expenditures on Shared Service Centers dropped from $1.45 \%$ to nearly $1.15 \%$. 


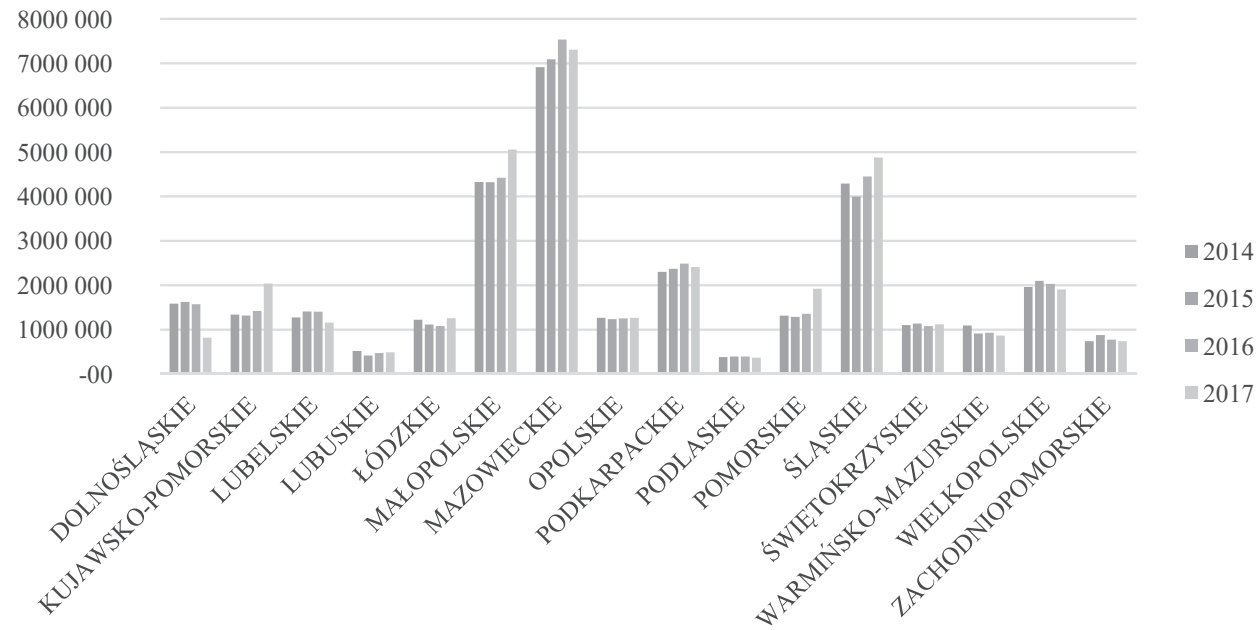

Figure 4. Average monthly remuneration of SSC/EASC administrative employees (in PLN) Source: own study based on data from the Ministry of National Education.

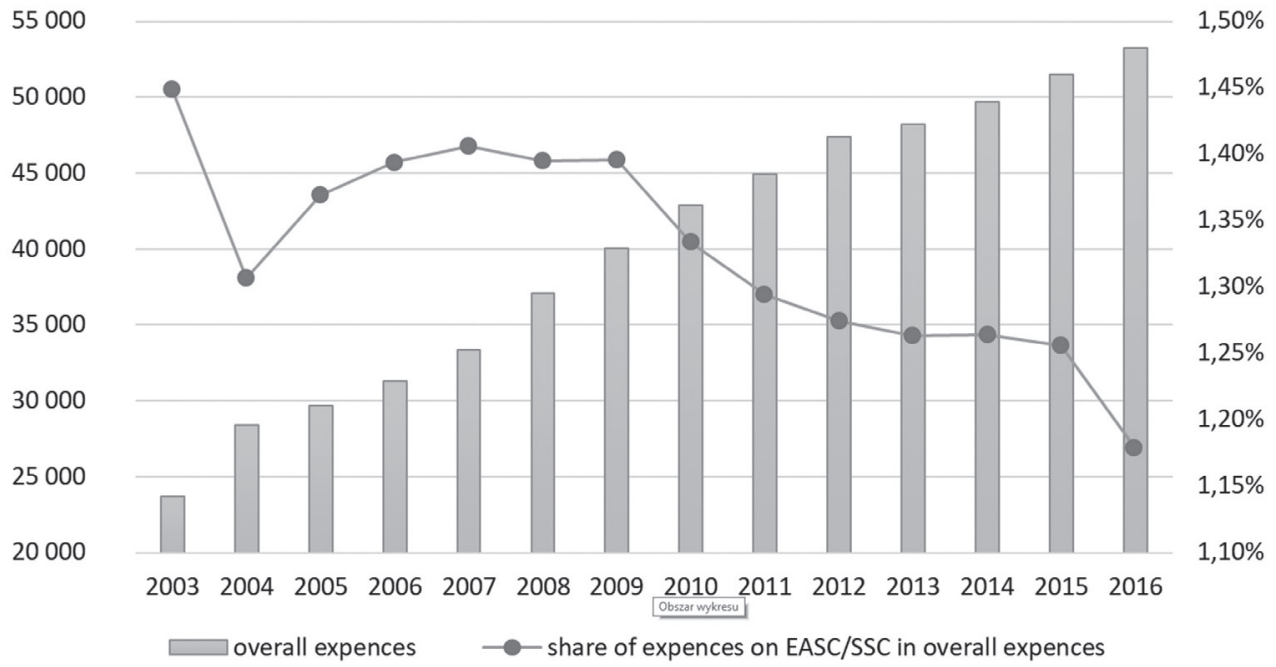

Figure 5. Share of expenditures on SSC / EASC in total expenditures of communes and cities with poviat rights in Poland in 2003-2016 (in million PLN)

Source: own study based on www.bdl.stat.gov.pl

The share of expenditures on SSC / EASC in the total expenditure of communes and cities with poviat rights in the voivodeship Podkarpackie is shown below graphically. 


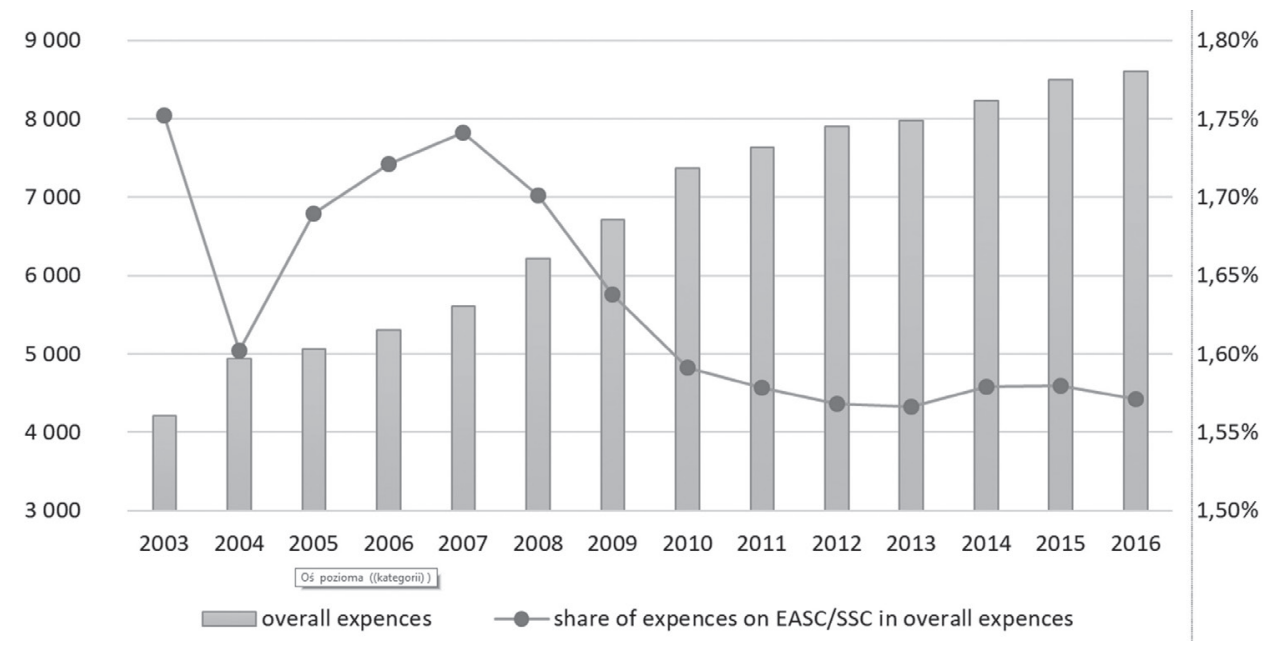

Figure 6. Share of expenditures on SSC / EASC in total expenditure of communes and cities with poviat rights in Podkarpackie voivodeship in the years 2003-2016 (in million PLN)

Source: own study based on www.bdl.stat.gov.pl

As can be seen from the chart above, the nationwide trend shown in the previous chart is also reflected in the Podkarpackie voivodeship. Although the total expenditure of communes and cities with poviat rights in the Podkarpackie voivodeship, in the period under review, systematically increased from just over PLN 4 million in 2003 to nearly PLN 9 million in 2016, the share of expenditure on SSC fell from 1.75\% to just over $1.55 \%$.

The above preliminary and very general analysis leads us to a deeper analysis of the selected topic and an attempt to assess the impact of back-office centralization as a part of Shared Service Centers on reducing costs and increasing the effectiveness of the support areas for communal educational institutions in the Podkarpackie voivodeship.

\section{Conclusions}

The introduction of a regulation that allows local governments to jointly serve organizational units should be assessed positively. The experience of the private sector as well as the public sector in other European countries shows that the creation of specialized entities serving other public entities in the field of financial or administrative tasks allows for a real optimization of global costs of public tasks. In particular, the flexibility of local governments in the new regulations should be assessed positively, as to the use of a new tool, namely Shared Service Centers. The decision on the scope of shared service, both in the subjective and objective dimension, is an autonomous decision of each unit. Therefore, local governments have the right to choose, as to the specialization of centers (e.g. human resources management), as well as their area of activity (e.g. health care facilities). 
The hypothesis formulated at the outset that the centralization of the support function of communal educational institutions results in a reduction of expenditure on the functioning of educational institutions communes of the voivoideship Podkarpackie turned out to be real. In the course of the conducted research, in 2014-2017 it was stated that in the Podkarpackie voivodeship, despite the growing total expenditure of communes and cities with poviat rights, the share of expenditure on SSC have decreased. This tendency was also observed throughout Poland. This allows the conclusion that from the point of view of the municipality's expenditure the beneficial, is the implementation of the auxiliary processes organization model implemented by support departments in self-government educational institutions in the form of Shared Service Centers due to a number of benefits, in a particular the possibility of reducing expenditure on tasks by not implemented with the unchanged quality of their services, and thus lowering the costs of their operations. At the same time, the educational institution will be able to concentrate on the basic tasks (to which it was established): to teach and raise children and young people and improve the quality of services provided.

\section{References:}

Cabinet Office. (2005). UK: Transformational Goverment. - Enabled by Technology HM Government.

Czepelak Z. (2015). Możliwość racjonalizacji kosztów działania placówek oświatowo-wychowawczych, w oparciu o przepisy dotyczące centrów usług wspólnych. Ekspertyzy 4(4).

Dz.U. (2015). Ustawa z dnia 25 czerwca 2015 r. o zmianie ustawy o samorządzie gminnym oraz niektórych innych ustaw, 1045.

Kougias I., Seremeti L., Kalogeras D. (2018). Learning: a tool for competitive, sustainable and secure entrepreneurial activity. Central European Review of Economics and Finance 23(1).

Liszka-Michałka K. (2018). Wstępna analiza podstaw prawnych dla działania jednostek samorządu terytorialnego w wybranych obszarach. Zwiazzek Miast Polskich, Ośrodek Rozwoju Edukacji.

Łukaszczyk Z. (2017). Centrum Usług Wspólnych sposobem na redukcję kosztów i standaryzację procesów przedsiębiorstwa na przykładzie KHW S.A. Zeszyty Naukowe Politechniki Śląskiej, Seria: Organizacja i Zarządzanie, 101.

Świetla K., Wójcik-Jurkiewicz M. (2017). Centrum Usług Wspólnych współczesną koncepcją adaptacji rozwiązań biznesowych na poziomie samorządów, [w:] Świetta K. (red.), Współczesne koncepcje adaptacji rozwiązań rachunkowości i rewizji finansowej w kontekście gospodarki opartej na usługach, Warszawa. 